Technical Paper

Special articles: Biomass

特集：バイオマス

\title{
Formulating Cost Efficient, Low Environmental Load Forestry Operations: Logging Residue Transportation and Infrastructure Provision for Broad-leaved Tree Harvesting
}

\author{
Yasushi SuzUKI ${ }^{*}{ }^{\dagger}$ and Tetsuhiko YoshimuRA $* 2$ \\ (Received February 18, 2019)
}

\section{経費と環境負荷低減のための森林作業の定式化および林地残材運搬と広葉樹収穫のための基盤整備への適用 鈴木保志 $* 1 \dagger$, 吉村哲彦 $* 2$}

We propose a simple formulation to determine achieved improvements on investment level as a function of work in a commercial forestry operation. Two trial approaches are presented. The first attempts to formulate the relationship between unit costs and environmental loads such as $\mathrm{CO}_{2}$ emissions and energy consumption as a function of logging residue transportation distance. In general, transportation efficiency increases with scale: modal transfer from small to large scale transportation can be achieved through enabling infrastructure investment, such as the provision of intermediate landings. In our case study, four transport capacities were considered (i.e. trucks with $0.35,2,4$ and $10 \mathrm{t}$ capacities), with loading by a grapple loader sited at an intermediate landing. The optimum formulation was then applied to the second trial, which focused on infrastructure development for broad-leaved species harvesting, namely the construction of forest road networks. Three modes of extraction were considered, grappling, winching and a simple cable system, with two levels of infrastructure provision: $2.5 \mathrm{~m}$ wide spur road networks using mini-forwarders and $3.0 \mathrm{~m}$ wide forest road networks using $0.45 \mathrm{~m}^{3}$ bucket class excavator machines. Application of the derived formulation indicated thresholds for when each of the modes or systems was most appropriate.

Key Words

Broad-leaved tree, Logging residue, Modal selection threshold, Transportation, Woody biomass

伐出作業において，目標とする改善を得るための妥当な投資程度を求める簡便な定式化を提案し，2つの事例に適用し た。第1の事例では, 林地残材運搬距離の関数として, 経費掞よび環境負荷すなわち二酸化炭素排出量とエネルギー消費 との関係の定式化を試みた。一般に, 運搬効率は規模と共に向上し, 中間土場のような基盤整備の実施により小規模運搬 から大規模運搬へのモード移行が達成される。この事例では, トラック 4 種類（積載量 $0.35,2,4$, および $10 \mathrm{t}$ ) を想定し, グラップルローダにより中間土場で積み換えを行うものとした。第 2 の事例では，広葉樹材伐出のための基盤整備，すなわ ち林内路網の開設に適用した。集材方法は直接集材, ウインチ集材, そして軽架線の3モードを, 基盤整備は林内作業車 用の道幅 $2.5 \mathrm{~m}$ の低規格作業道路網と, バケット容量 $0.45 \mathrm{~m}^{3}$ の油圧ショベルベースマシン用の道幅 $3.0 \mathrm{~m}$ の高規格作業 道路網の 2 種類を想定した。提案した定式化手法により，最適なモードあるいは作業システムを選択するための閾値を得る ことが可能となった。

キーワード

広葉樹，林地残材，モード選択の閾値，輸送，木質バイオマス

$※ 1$ Faculty of Agriculture and Marine Science, Kochi University B200 Monobe, Nankoku, Kochi 783-8502, Japan

$※ 2$ Faculty of Life and Environmental Science, Shimane University 1060 Nishikawatsu, Matsue, Shimane 690-8504, Japan

$\uparrow$ Corresponding author: ysuzuki@kochi-u.ac.jp
$※ 1$ 高知大学農林海洋科学部 厂 783-8502 高知県南国市物部乙 200

※2 島根大学生物資源科学部 于 690-8504 島根県松江市西川津町 1060 


\section{1. 諸 言}

林地残材等の木質バイオマスを，地域での熱利用や発電 の目的のために林地から利用施設まで収集運搬する需要が, 近年高まっている ${ }^{1) ~-5)}$ 。収集対象となる残材等が, 積載質 量 $10 \mathrm{t}$ 級の大型トラックが通行可能な規格の高い作業道や 林道の道脇あるいはそうした道に隣接する土場に集積されて いる場合には，利用施設までの運搬は効率の高い大型トラッ クのみを用いて行うことができる ${ }^{6)} \sim 10$ )。林業で用いられる 生産基盤としての林内路網は, 一般に, 公道から林道, 林 業専用道, 森林作業道というように, 高規格 (幅員が広い) から低規格（幅員が狭い）へと段階的に整備され，これに より全体的な経済性と細部への到達性が確保される $\left.{ }^{11)} \sim 13\right) 。$ 数十から数百 ha 規模の森林施業団地で計画的に団地内に おける伐出から団地外への運材を実施できる場合には，団 地外から大型トラックが進入可能な場所に団地内土場を設 け，伐出作業の一環としてその団地内土場まで用材や残材を 集積し, 団地外への運搬は大型トラックを用いることができ るようにされる場合が多い14)

一方，地域の木質バイオマス利用事業などで近年多く用い

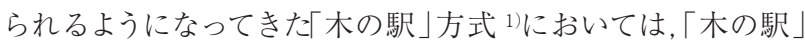
への出荷者は経営規模が小さい個人林家等が多くを占めて いる。個人林家による出荷では, 団地化や系統的な路網の 整備がされていない林地から，軽トラックや $2 \mathrm{t}$ あるいは $4 \mathrm{t}$ トラックなどにより, 場合によっては数十 $\mathrm{km}$ の距離を, 直接, 集積土場 (木の駅) まで林地残材等が運搬される事例も見 受けられる15)。このような非経済性を改善するため, 田内ら (2016) ${ }^{16)}$ は，2007〜2011 年度まで高知県仁淀川町で実施 された「木の駅」方式による木質バイオマス利用事業の実績 データをもとに, 町内の廃校となった学校跡地など 19 ヶ所 を中間土場として設定し，個々の出荷者は最寄りの中間土場 まで運搬し中間土場からは各中間土場を巡回する大型トラッ クで町外の利用施設まで運搬する方式を提案し，GIS を用い た試算からこの方式により収益性が大きく向上することを示 した。これは，中間土場の設置と積み替えという投資により 運搬単価の高い小規模運搬モードから運搬単価の低い大規 模運搬モードへの移行を可能にし，投資により全体の経費 が低下した，すなわち正の投資効果が得られたと解釈でき る。ただし，投資を行っても，例えば大規模運搬モードに 移行してからの運搬距離が十分でなければ，全体としての 効率はかえって低下する場合もある。

そこで本研究では，この投資によるモード移行の関係を 定式化し，第1の事例として林地残材等の運搬における投 資効果と運搬距離の分析に適用する。投資効果については, 経費のほか, 環境負荷の指標として $\mathrm{CO}_{2}$ 排出量とエネルギー 消費を用いて評価する。

木質バイオマス発電の燃料材供給については, 高知県の 西部において過去の薪炭林など一定面積の未利用広葉樹林 を団地化して森林経営計画も立てて皆伐し, 得られた材を認 証未利用材として数十年の回帰年で循環利用する方法が検 討されている8)10)。これらの事例では，皆伐し支間約 $500 \mathrm{~m}$
の架線による集材を行う方式で実証試験と詳細な収支状況 の検討が行われている。しかし, 広葉樹材は, 樹種および 径級や材質によっては高価值で取引きされるものもあり，間 伐施業を繰り返し適切な森林施業を行いながら, 持続可能 な管理経営と収穫を両立していくことが望まれる17) 18)。そう した森林施業は，間伐に適した軽架線やグラップルによる 直接集材による収穫ができるよう，集材距離が $100 \mathrm{~m}$ 以下 程度となる路網整備により可能となる。そこで第 2 の事例で は, 路網整備を投資とし, 広葉樹材の収穫経費の低減を投 資効果として，定式化を適用する。

\section{2. 方 法}

\section{1 定式化}

目的とする仕事や作業の量を $x$ (事例 1 では運搬距離 $[\mathrm{km}]$ ，事例 2 では集材量 $\left.\left[\mathrm{m}^{3}\right]\right)$ ，それにより生じる経費や 負荷を $y[\mathrm{U}]$ （経費や負荷の単位を一般化して [U] とするが, 事例 1 では運搬単位量あたり $\left[\mathrm{U} \cdot \mathrm{t}^{-1}\right]$ で表す）とする。運搬 や集材の効率は, 単位仕事量あたりの経費あるいは負荷 $s$ (事 例 1 では $\left[\mathrm{U} \cdot \mathrm{t}^{-1} \cdot \mathrm{km}^{-1}\right]$ ，事例 2 では $\left[\mathrm{U} \cdot \mathrm{m}^{-3}\right]$ ) で表されるも のとする。一般に $y$ は定数項を含む $x$ の1次式で表されるが, 後述の LCA ソフトで得られる環境負荷指標は, 定数項のな い, 運搬量や距離に比例する係数のみで表されるため, 本 論の定式化ではこれに従って単位運搬量あたり経費や環境 負荷を表すこととする。よって $y$ は次式のように定数項のない 1 次式となる。

$y=s \cdot x$

より効率が低い小規模な手段 (モード1) では，より効率 が高い大規模な手段（モード 2$)$ よりも $s$ が大きい $\left(s_{1}>s_{2}\right.$, Fig. 1)。このため, どちらの手段も利用可能な状況では, モー ド 2 が選択される。

木の駅に出荷する小規模林家のようにモード 1 しか用いる ことができない状況では, 運搬の出発地点ではモード 1 が 用いられる。中間土場の設置と積み替えという投資 $I\left[\mathrm{U} \cdot \mathrm{t}^{-1}\right]$ が運搬距離 $L_{1}[\mathrm{~km}]$ の地点で行われると, 経費・負荷はこ

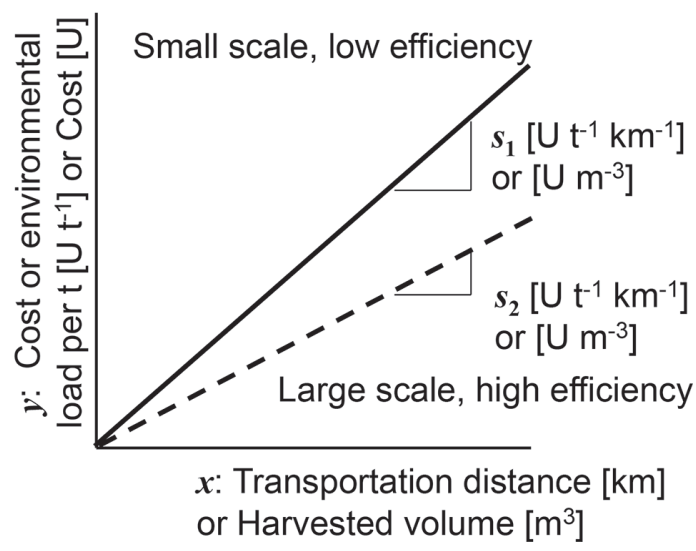

Fig. 1 General relationship between cost or environmental load and transportation distance for different transportation modes 


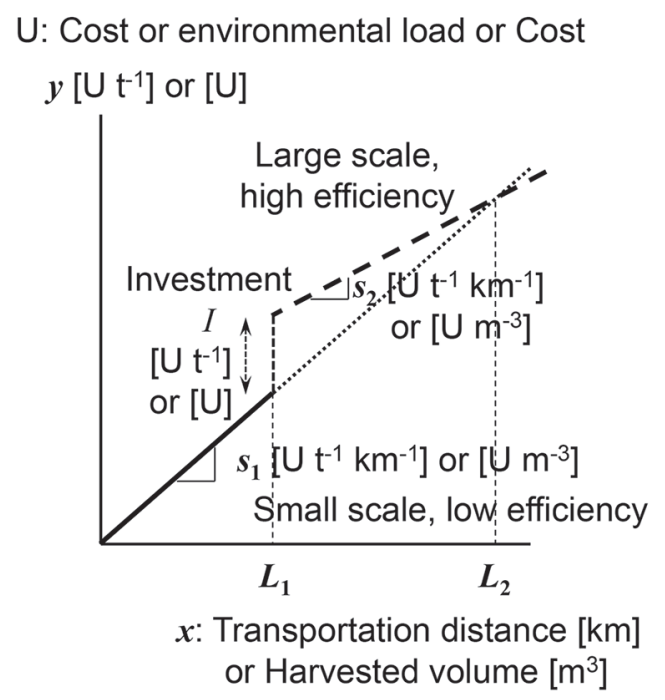

Fig. 2 Transformation of first mode to second transportation mode with an investment

の地点で $I\left[\mathrm{U} \cdot \mathrm{t}^{-1}\right]$ の分だけ増加する。以降の運搬はモード 2 で行われ, 総運搬距離が一定の值 $L_{2}[\mathrm{~km}]$ を超えると, $I$ $\left[\mathrm{U} \cdot \mathrm{t}^{-1}\right]$ を含めても総経費・負荷 $y[\mathrm{U}]$ はモード1のままで運 搬された場合よりも低くなる (Fig. 2)。この $L_{2}$ と $L_{1}$ の差は, 投資効果が有効すなわち正となるような, 中間土場から最終 運搬目的地の利用施設までの距離を意味しており, 以下の式 で求められる。

$$
L_{2}-L_{1}=I /\left(S_{1}-S_{2}\right)
$$

事例 2 において $x$ は集材量となる。投資 $I$ は路網整備, 寸 なわち作業道等の開設量であり, その性質上 ha あたりの開 設量 $\left[\mathrm{m} \cdot h \mathrm{~h}^{-1}\right]$ で表すことが合理的である。そこで, 事例 2 においては, $x$ も haあたりの集材量 $\left[\mathrm{m}^{3} \cdot \mathrm{ha}^{-1}\right]$ として表すこと とする。

\section{2 適用事例}

\subsection{1 事例 $1:$ 林地残材運搬}

運搬モードとして, より小規模から大規模なものへの移行 を表現できるよう, 軽トラック（積載量 0.35 t） と積載量 2 , 4, $10 \mathrm{t}$ のトラックの 4 種類を想定した。土場への投資は, 土場そのものは田内ら (2016) ${ }^{16)}$ に倣い空き地等を利用する ものとして経費等は計上せず, 土場における標準バケット容 量 $0.45 \mathrm{~m}^{3}$ クラスの油圧ショベルをベースマシンとするグラッ プルローダによる積み替えのみを考慮する。

車両の経費は, 軽トラックと $2 \mathrm{t}$ および $4 \mathrm{t}$ トラックについ は鈴木ら (2013) ${ }^{15)}$ から, 燃料費の変動を考慮して求められ ている 2 種類の機械の時間費用の平均(それぞれ 814, 1,635, 2,610 [円・時-1]）に人件費 2,725 [円・時-1] を加えた值を, 往復を考慮して 2 倍し, それを平均速度 $35[\mathrm{~km} \cdot$ 時-1] とそ れぞれの積載量 $(0.35,2,4[\mathrm{t}])$ で割ることで得た（単位は $\left[\right.$ 円 $\left.\left.\cdot \mathrm{t}^{-1} \cdot \mathrm{km}^{-1}\right]\right)$ 。 $10 \mathrm{t}$ トラックについては岩岡 (2013) 6) から 材積あたりの值 $23.5\left[\right.$ [円 $\cdot \mathrm{m}^{-3} \cdot \mathrm{km}^{-1}$ ] に質量から材積への変 換係数 $1.3\left[\mathrm{~m}^{3} \cdot \mathrm{t}^{-1}\right]{ }^{4)}$ を掛けて得た。グラップルローダの経
費は，森口ら $(2004)^{7)}$ から，人件費も含めた時間費用 4,705 [円・時-1］を積込み生産性 11.250[t・時-1] で割ることで得た。 車両とグラップルローダの環境負荷は JEMAI（一般社団 法人産業環境管理協会）の LCA ソフトMiLCA ver. 1.1 およ び IDEA ver. 1.1 を用いて算出した。車両については, 同ソ フトのデータベースから機械の製造廃棄に関わるものと使用 時の燃料消費を含めたものとして運搬量あたり・運搬距離あ たりで值を得た。グラップルローダについては, 得られた值 は機械の製造に関わるもののみであったため, 全国林業改 良普及協会編 (2001) 19) から得たグラップルローダ大の耐用 時間 9,480 時間と積込み生産性 $11.250\left[\mathrm{t} \cdot\right.$ 時 -1] ${ }^{7}$ ) でこの得 られた值（グラップルローダの製造に関わる環境負荷）を割 り，製造に関わる環境負荷（積込み量 $\mathrm{t}$ あたり）として值を 得た。作業に伴う燃料消費に関わる負荷については, 環境省 (2019) ${ }^{20)}$ から得た軽油の $\mathrm{CO}_{2}$ 排出係数 $2.585\left[\mathrm{~kg}-\mathrm{CO}_{2} \mathrm{e} \cdot \mathrm{L}^{-1}\right]$ およびエネルギー原単位 $37.7\left[\mathrm{MJ} \cdot \mathrm{L}^{-1}\right]$ に, それぞれ, 仲畑 ら (2004) 21)による同種の機械を用いた木寄せ作業の燃料消 費率 7.84 [L·時 -1] を掛け, 積込み生産性 $11.250\left[\mathrm{t} \cdot\right.$ 時 -1 ${ }^{-1}$ 7) で割ることで算出し，製造に関わる環境負荷と合計したもの をグラップルローダの環境負荷 $\left(\mathrm{CO}_{2}\right.$ 排出量 $\left[\mathrm{kg}-\mathrm{CO}_{2} \mathrm{e} \cdot \mathrm{t}^{-1}\right]$ およびエネルギー消費 $\left[\mathrm{MJ} \cdot \mathrm{t}^{-1}\right]$ ）とした。

運搬車両について得られたこれらの経費と環境負荷を, それぞれの運搬モードの $s\left(\left[\mathrm{U} \cdot \mathrm{t}^{-1} \cdot \mathrm{km}^{-1}\right], \mathrm{U}\right.$ の単位は経費 については [円], 環境負荷については $\mathrm{CO}_{2}$ 排出量 $\left[\mathrm{kg}-\mathrm{CO}_{2} \mathrm{e}\right]$ およびエネルギー消費 $[\mathrm{MJ}]$ ）とした。グラップルローダにつ いて得られた経費と環境負荷を投資 $I\left[\mathrm{U} \cdot \mathrm{t}^{-1}\right]$ とし, (2) 式 により小規模モードから大規模モードに移行した場合に投資 効果が正となる距離 $L_{2}-L_{1}[\mathrm{~km}]$ を算出した。

\section{2 .2 事例 $2:$ 広葉樹収穫と路網整備}

収穫対象とする広葉樹林内に路網を作設し, 架設の容易 な軽架線や単線ウインチ集材 (単引き集材)，あるいはグラッ プルによる直接集材を実施する状況を想定する。ランニング スカイライン等による軽架線集材の適切な集材距離は $100 \mathrm{~m}$ 程度以下, 単引き集材は $50 \mathrm{~m}$ 程度以下, 直接集材は $25 \mathrm{~m}$ 程度以下とされている22）23)。路網の配置が良好な場合を想 定し道路の迂回率を 1 とすると, 路網密度 $R D\left[\mathrm{~m} \cdot \mathrm{ha}^{-1}\right]$ にお ける最大集材距離 $d[\mathrm{~m}]$ は以下の式で与えられる ${ }^{11)}{ }^{24)}$ 。

$$
d=5,000 / R D
$$

実際の集材距離は，伐倒木の樹高が $15 \sim 20 \mathrm{~m}$ 程度あるの で, $d$ よりもその分短くなる。なお，平均集材距離は $d / 2[\mathrm{~m}]$ であり, 集材線の迁回を考慮すると $d$ には集材線の迂回係数 (1.3〜 1.5 程度) を乗ずる必要がある11) 24) が, 架線系の 集材および直接集材では根株位置から直線的に材を引き出 すため集材線の迂回係数は 1 とみなされ, (3) 式により $R D$ のみから $d$ を求めることができる。

集材に用いる機械・作業システムとそれに対応する道の規 格は, 林内作業車や標準バケット容量 $0.25 \mathrm{~m}^{3}$ クラスの油圧 ショベルをベースマシンとする機械を用いるための幅員 $2.5 \mathrm{~m}$ の低規格作業道と, $0.45 \mathrm{~m}^{3}$ クラスの機械を用いるための幅 員 $3.0 \mathrm{~m}$ の高規格作業道の 2 種類とする (Fig. 3)。低規格 


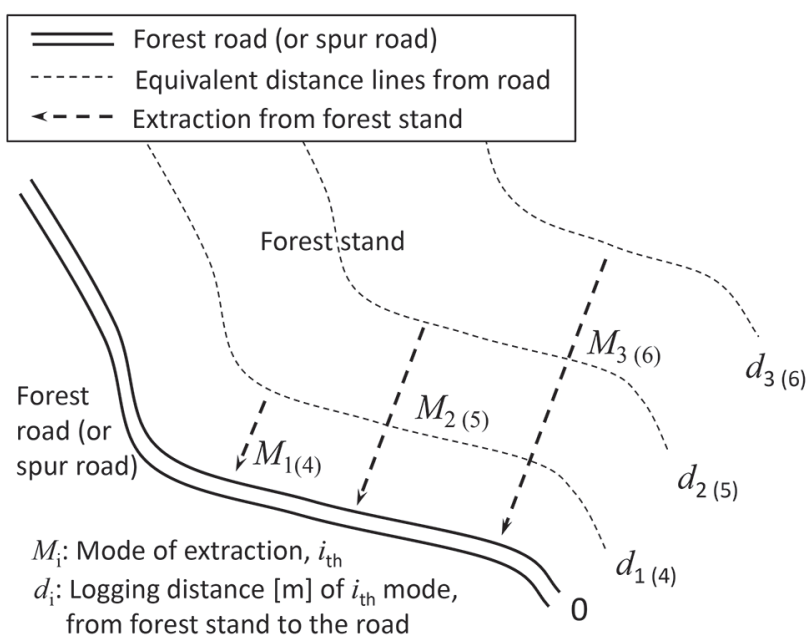

Fig. 3 Mode of extraction and logging distance from forest stand to the road

作業道の路網・作業システムにおいて，林内作業車はウイ ンチを装備しているため, 運材作業に加えて軽架線を架設 し $100 \mathrm{~m}$ 程度の支間距離までの集材作業を行うことができ る ${ }^{25)}$ 。集材距離が $50 \mathrm{~m}$ 程度以下になると, より効率の高い 索張りを用いない単引き集材が可能となる22) 23)。軽架線集 材と単引き集材における作業組人数は荷掛け手を含めて 2 人 で，いずれも $0.20 \mathrm{~m}^{3}$ クラスのグラップル付き油圧ショベル を組み合わせて用いるものとする ${ }^{26)}$ 。造材はチェンソーで行 われる。直接集材を実施できる路網密度では, $0.25 \mathrm{~m}^{3}$ ク ラスのプロセッサが 1 人作業で集造材を同時に行うものとし た。

高規格作業道の路網・作業システムでは，造材は $0.45 \mathrm{~m}^{3}$ クラスのプロセッサにより行うものとする。軽架線はスイング ヤーダ (0.45 m³ クラス) によるランニングスカイライン式によ るものとし，単引きはプロセッサ搭載の小型ウインチで行う ものとする。いずれでも荷掛け手が 1 人必要であり，作業組 人数は荷掛け手を含めて 2 人となる。直接集材は低規格作 業道の場合と同じく， $0.45 \mathrm{~m}^{3}$ クラスのプロセッサによる 1 人 作業とする。

事例 2 では経費のみを評価することとし，人件費と機械の
時間経費，各作業の生産性は既報 13) 25)～27) から得た。参 考にした生産性はいずれもスギ・ヒノキなど針葉樹人工林に おける間伐作業における值である。広葉樹の間伐作業にお ける生産性の実績值は現時点では得られていないが, ハー ベス夕による広葉樹や曲がりの多い針葉樹の集造材の生 産性は通直な材に比べて 2 割程度低下するという報告があ る ${ }^{28)}{ }^{29)}$ 。従って, 実際の集造材経費は 2 割増し程度となる ことが考えられる。

各作業システムにおいて，人件費と使用する機械の時間経 費の合計 [円・組 ${ }^{-1}$. 時 -1] 作業の組生産性 [ $\mathrm{m}^{3}$ ・組 ${ }^{-1}$ ・時 -1 1 ] で割ることにより，材積あたりの伐出経費 $\left[\right.$ 円 $\left.\cdot \mathrm{m}^{-3}\right]$ が得ら れる27)。これがFig. 2 における $s$ となる。

以上に抏て, 伐出作業のうち集造材のみを計算の対象と している。伐木作業はチェンソー1台を用いる 1 人組作業でい ずれの作業システム (モード) でも共通のため, 移行対象と なる2つのモード間の作業経費を比較する本研究の目的にお いては除外しても影響はない。Setiawan et al. (2013) 27) と鈴 木ら (2015) ${ }^{13)}$ の人件費を含む組作業経費 [円・組 ${ }^{-1}$. 時 -1 ${ }^{-1}$ ] と Nakahata et al. (2014) ${ }^{30)}$ の組生産性 $\left[\mathrm{m}^{3}\right.$. 組 ${ }^{-1}$. 時 -1 $]$ か ら伐木作業の伐出経費を求めると $340\left[\right.$ 円 $\left.\cdot \mathrm{m}^{-3}\right]$ となる。

路網の開設費は，低規格作業道については高知県の造林 補助金制度における標準単価 ${ }^{31)}$ を参考に 3,000 [円 $\cdot \mathrm{m}^{-1}$ ] , 高規格作業道については山㟝ら (2018) 14) の実績值を参考 に 7,000 [円· $\left.\mathrm{m}^{-1}\right]$ とした。モード間の移行に必要な追加の 開設費は開設単価に路網密度の増加分を掛けたものであり, これが投資 $I[$ 円・ha-1] となる。

\section{3. 結果と考察}

\section{1 事例 $1:$ 林地残材運搬}

4 種類の運搬モードについて, 得られた単位運搬量・単 位運搬距離あたり経費と環境負荷 $s$ の值をTable 1 に, 中 間土場における積み替え経費の単位量あたり経費と環境負 荷 $I$ の值を Table 2 に示す。いずれも有効数字 3 桁とした。 Table 1 において, 経費と 2 種類の環境負荷は高い相関を示 した $(n=4, r=0.9970 \sim 1.000, P<0.01)$ 。

(2) 式により求めた，小規模モードから大規模モードに移 行した場合に投資効果が正となる距離 $L_{2}-L_{1}[\mathrm{~km}]$ を, 経費

Table 1 Unit cost and environmental load of transportation

\begin{tabular}{|c|c|c|c|c|}
\hline Items & Light truck & $2 \mathrm{t}$ truck & $4 \mathrm{t}$ truck & $10 \mathrm{t}$ truck \\
\hline Payload [t] & 0.35 & 2 & 4 & 10 \\
\hline Cost $\left[\mathrm{JPY} \cdot \mathrm{t}^{-1} \cdot \mathrm{km}^{-1}\right]$ & $5.78 \cdot 10^{2}$ & $1.25 \cdot 10^{2}$ & $7.62 \cdot 10^{1}$ & $3.06 \cdot 10^{1}$ \\
\hline $\mathrm{CO}_{2}$ emissions $\left[\mathrm{kg}-\mathrm{CO}_{2} \mathrm{e} \cdot \mathrm{t}^{-1} \cdot \mathrm{km}^{-1}\right]$ & $1.52 \cdot 10^{\circ}$ & $5.04 \cdot 10^{-1}$ & $3.22 \cdot 10^{-1}$ & $1.76 \cdot 10^{-1}$ \\
\hline Energy consumption $\left[\mathrm{MJ} \cdot \mathrm{t}^{-1} \cdot \mathrm{km}^{-1}\right]$ & $2.15 \cdot 10^{1}$ & $6.94 \cdot 10^{0}$ & $4.41 \cdot 10^{0}$ & $2.42 \cdot 10^{\circ}$ \\
\hline
\end{tabular}

Table 2 Unit cost and environmental load of loading

\begin{tabular}{lccc}
\hline \multicolumn{1}{c}{ Items } & $\begin{array}{c}\text { Cost } \\
{\left[\mathrm{JPY} \cdot \mathrm{t}^{-1}\right]}\end{array}$ & $\begin{array}{c}\mathrm{CO}_{2} \text { emissions } \\
{\left[\mathrm{kg}-\mathrm{CO}_{2} \mathrm{e} \cdot \mathrm{t}^{-1}\right]}\end{array}$ & $\begin{array}{c}\text { Energy consumption } \\
{[\mathrm{MJ} \cdot \mathrm{t}-1]}\end{array}$ \\
\hline Assembling of equipment & $\mathrm{N} . \mathrm{A}$. & $1.28 \cdot 10^{-1}$ & $1.58 \cdot 10^{0}$ \\
Fuel consumption on operation & $\mathrm{N} . \mathrm{A}$. & $1.80 \cdot 10^{0}$ & $2.66 \cdot 10^{1}$ \\
Total & $7.60 \cdot 10^{2}$ & $1.93 \cdot 10^{0}$ & $2.82 \cdot 10^{1}$ \\
\hline
\end{tabular}


については Table 3 に，環境負荷である $\mathrm{CO}_{2}$ 排出量とエネル ギー消費量についてはそれぞれ Table 4 および Table 5 に示 す。軽トラックからより大規模のモードへの移行について得 られた $L_{2}-L_{1}$ はいずれも $2 \mathrm{~km}$ 以下で, これは軽トラックが 特に効率が悪いことを示していると考えられる。 $2 \mathrm{t}$ から $4 \mathrm{t}$ トラックおよび $4 \mathrm{t}$ から $10 \mathrm{t}$ トラックへの移行についての值 は $11 \sim 17 \mathrm{~km}$ 程度となっており，これら 2 モード間の効率 の差は他の組み合わせほど大きくないと言える。一方, $2 \mathrm{t}$ 卜 ラックから $10 \mathrm{t}$ トラックへの移行については $6 \sim 8 \mathrm{~km}$ 程度 で, 効率の差は今回比較した事例の中では中程度である。

軽トラックは，木の駅事業で個人林家により高い割合で 利用されている運搬手段である。中山間地では軽トラックの 普及率は高いと思われ，気軽に利用できる運搬手段でもあ るが, 経費・環境負荷ともに効率の悪い運搬手段であるこ とが確認された。こまめに中間土場を設け，大型トラックで

Table 3 Distance $L_{2}-L_{1}[\mathrm{~km}]$ on cost [JPY·t-1]

\begin{tabular}{l|rrrr}
\hline \multirow{2}{*}{1 st mode } & \multicolumn{4}{|c}{ 2nd mode } \\
& Light truck & 2t truck & 4t truck & 10t truck \\
\hline Light truck & & 1.7 & 1.5 & 1.4 \\
$2 \mathrm{t}$ truck & N.A. & & 15.7 & 8.1 \\
$4 \mathrm{t}$ truck & N.A. & N.A. & & 16.7 \\
$10 t$ truck & N.A. & N.A. & N.A. & \\
\hline
\end{tabular}

Table 4 Distance $L_{2}-L_{1}[\mathrm{~km}]$ on $\mathrm{CO}_{2}$ emissions $\left[\mathrm{kg}-\mathrm{CO}_{2} \mathrm{e} \cdot \mathrm{t}^{-1}\right]$

\begin{tabular}{l|rrrr}
\hline \multirow{2}{*}{1 st mode } & \multicolumn{4}{|c}{ 2nd mode } \\
& Light truck & 2t truck & 4 t truck & $10 t$ truck \\
\hline Light truck & & 1.9 & 1.6 & 1.4 \\
$2 \mathrm{t}$ truck & N.A. & & 10.6 & 5.9 \\
$4 \mathrm{t}$ truck & N.A. & N.A. & & 13.2 \\
$10 t$ truck & N.A. & N.A. & N.A. \\
\hline
\end{tabular}

Table 5 Distance $L_{2}-L_{1}[\mathrm{~km}]$ on energy consumption $\left[\mathrm{MJ} \cdot \mathrm{t}^{-1}\right]$

\begin{tabular}{l|rrrr}
\hline \multirow{2}{*}{1 st mode } & \multicolumn{4}{|c}{ 2nd mode } \\
& Light truck & 2t truck & 4 t truck & 10t truck \\
\hline Light truck & & 1.9 & 1.6 & 1.5 \\
$2 \mathrm{t}$ truck & N.A. & & 11.1 & 6.2 \\
$4 \mathrm{t}$ truck & N.A. & N.A. & & 14.2 \\
$10 t$ truck & N.A. & N.A. & N.A. & \\
\hline
\end{tabular}

なくとも $4 \mathrm{t}$ あるいは $2 \mathrm{t}$ トラックによる運搬に距離的に早 めに移行できるようにすることが得策であろう。地域での木 質バイオマス事業の対象範囲は, 少ない事例数からではあ るが半径 $30 \mathrm{~km}$ 程度以内である場合が多いものと推察され る 1) 3） 7) 9） 15）16) 4 t トラックの効率性は 10 tトラックに比べ ても大きな遜色はないため, 運搬の出発点から $4 \mathrm{t}$ トラック が利用できるような路網整備が用意されていれば, 多くの場 合, 中間土場の必要性は高くないものと考えられる。

\section{2 事例 2 : 広葉樹収穫と路網整備}

Table 6 には, 路網に用いられる作業道の規模別に, 基 盤整備すなわち路網密度の段階とそれぞれの段階で用いら れる伐出手段の組み合わせを一覧にして示した。集材距離 $100 \mathrm{~m}$ の軽架線を用いるためには, まず $50\left[\mathrm{~m} \cdot \mathrm{ha}^{-1}\right]$ の密度 の基盤路網を整備する必要がある。この段階をモード1（低 規格作業道）または 4（高規格作業道）とする。より集材 距離が短い単引き集材が実行できるよう, ha あたり $50 \mathrm{~m}$ 分 の路網を追加する投資を行って路網密度を $100\left[\mathrm{~m} \cdot \mathrm{ha}^{-1}\right]$ に 高めると，モード 1 から 2 , あるいはモード4から 5 への移 行が可能となる。さらに, haあたり $100 \mathrm{~m}$ 分の路網を追加 して開設すると最大集材距離は $25 \mathrm{~m}$ まで短縮され, 作業 道上に位置する機械がアーム・ブームを伸ばして伐倒木を直 接グラップルで把持して集材を行う直接集材が実施可能とな る(モード2から 3 ，あるいはモード5から 6 への移行)。あ るいは，モード1または 4 の状態で一気に haあたり $150 \mathrm{~m}$ 分の路網開設を行えば，モード 2 または 5 を飛ばしてモード 3 または 6 に移行することも可能である。このような, モード 1から 2，3，あるいはモード4から $5 ， 6$ への移行について 検討した。計算に用いる時間費用の一覧を Table 7 に, そ れぞれのモードにおける作業システムの人員と使用機械およ び生産性, システムの時間経費, 単位集材量あたり経費の 一覧を Table 8 に示す。

単位集材量あたり経費は, 低規格あるいは高規格の作業 道路網を基盤とするそれぞれのシステムにおいて, 低効率 (集 材距離が長い)のモードよりも高効率 (集材距離が短い) の モードの方が低い值になるのが妥当である。しかし, 高規 格路網のモード6は 3,306 [円 $\cdot \mathrm{m}^{-3}$ ］とモード5の 2,940［円

Table 6 Extraction mode corresponding to infrastructure, extraction distance, and investment

\begin{tabular}{|c|c|c|c|c|c|c|c|}
\hline \multirow{2}{*}{$i$} & \multirow{2}{*}{$M_{\mathrm{i}}($ Mode $)$} & \multirow{2}{*}{$\begin{array}{c}d_{\mathrm{i}} \text {, Logging } \\
\text { distance } \\
{[\mathrm{m}]}\end{array}$} & \multirow{2}{*}{$\begin{array}{c}\text { Road } \\
\text { density } \\
{\left[\mathrm{m} \cdot \mathrm{ha}^{-1}\right]}\end{array}$} & \multirow{2}{*}{$\begin{array}{c}\text { Unit cost } \\
\text { of road } \\
\text { construction } \\
{\left[\mathrm{JPY} \cdot \mathrm{m}^{-1}\right]}\end{array}$} & \multicolumn{3}{|c|}{$I$ (Investment) } \\
\hline & & & & & Transfer & {$\left[\mathrm{m} \cdot \mathrm{ha}^{-1}\right]$} & {$\left[\mathrm{JPY} \cdot \mathrm{ha}^{-1}\right]$} \\
\hline \multicolumn{3}{|c|}{ Spur road, $2.5 \mathrm{~m}$ width for mini-forwarder and $0.25 \mathrm{~m}^{3}$ class excavator } & & 3,000 & Basic: 0 & & 0 \\
\hline 1 & Cable system by mini-forwarder mounted winch & 100 & 50 & & 0 to 1 & 50 & 150,000 \\
\hline 2 & Winching & 50 & 100 & & 1 to 2 & 50 & 150,000 \\
\hline 3 & Grappling & 25 & 200 & & 2 to 3 & 100 & 300,000 \\
\hline \multicolumn{2}{|c|}{ Forest road, $3.0 \mathrm{~m}$ width for $0.45 \mathrm{~m}^{3}$ class excavator } & & & 7,000 & Basic: 0 & & 0 \\
\hline 4 & Cable system by excavator mounted double winch & 100 & 50 & & 0 to 1 & 50 & 350,000 \\
\hline 5 & Winching & 50 & 100 & & 1 to 2 & 50 & 350,000 \\
\hline 6 & Grappling & 25 & 200 & & 2 to 3 & 100 & 700,000 \\
\hline
\end{tabular}


Table 7 List of hourly costs

\begin{tabular}{lrl}
\hline \multicolumn{1}{c}{ Item } & $\begin{array}{l}\text { Hourly cost } \\
{\left[J P Y \cdot h o u{ }^{-1}\right]}\end{array}$ & \multicolumn{1}{l}{ Source } \\
\hline Operator & 2,725 & Setiawan et al. $(2013)^{27)}$ \\
\hline Chainsaw & 346 & Setiawan et al. $(2013)^{27)}$ \\
\hline Mini-forwarder & 2,060 & Suzuki et al. $(2015)^{13)}$ \\
\hline Grapple, $0.20 \mathrm{~m}^{3}$ & 1,898 & Setiawan et al. $(2013)^{27)}$ \\
\hline Processor, $0.25 \mathrm{~m}^{3}$ & 4,875 & Setiawan et al. $(2013)^{27)}$ \\
\hline Swing yarder, $0.45 \mathrm{~m}^{3}$ & 6,449 & Setiawan et al. $(2013)^{27)}$, no subsidy \\
\hline Processor, $0.45 \mathrm{~m}^{3}$ & 7,164 & Setiawan et al. $(2013)^{27)}$, no subsidy \\
\hline
\end{tabular}

Note: The standard bucket capacities, i.e., $0.20,0.25,0.45 \mathrm{~m}^{3}$, indicate corresponding sizes of excavator-based machines.

Table 8 Logging systems configuration

\begin{tabular}{|c|c|c|c|c|c|c|c|c|c|c|c|c|c|}
\hline$i$ & $M$ & $\begin{array}{c}\text { Number of } \\
\text { crew }[\mathrm{N}]\end{array}$ & Chasor & Chainsaw & $\begin{array}{c}\text { Mini- } \\
\text { forwarder }\end{array}$ & $\begin{array}{c}\text { Grapple, } \\
0.20 \mathrm{~m}^{3}\end{array}$ & $\begin{array}{c}\text { Processor, } \\
0.25 \mathrm{~m}^{3}\end{array}$ & $\begin{array}{l}\text { Swing } \\
\text { yarder, } \\
0.45 \mathrm{~m}^{3}\end{array}$ & $\begin{array}{c}\text { Processor, } \\
0.45 \mathrm{~m}^{3}\end{array}$ & $\begin{array}{c}\text { Productivity } \\
{\left[\mathrm{m}^{3} \cdot \mathrm{crew}-\right.} \\
\left.\text { hour }{ }^{-1}\right]\end{array}$ & $\begin{array}{c}\text { Hourly } \\
\text { cost } \\
{[\mathrm{JPY} \cdot \mathrm{crew}-} \\
\left.\text { hour }{ }^{-1}\right]\end{array}$ & $\begin{array}{c}\text { Resulting } \\
\text { cost } \\
{\left[\mathrm{JPY} \cdot \mathrm{m}^{-3}\right]}\end{array}$ & Source and notes \\
\hline
\end{tabular}

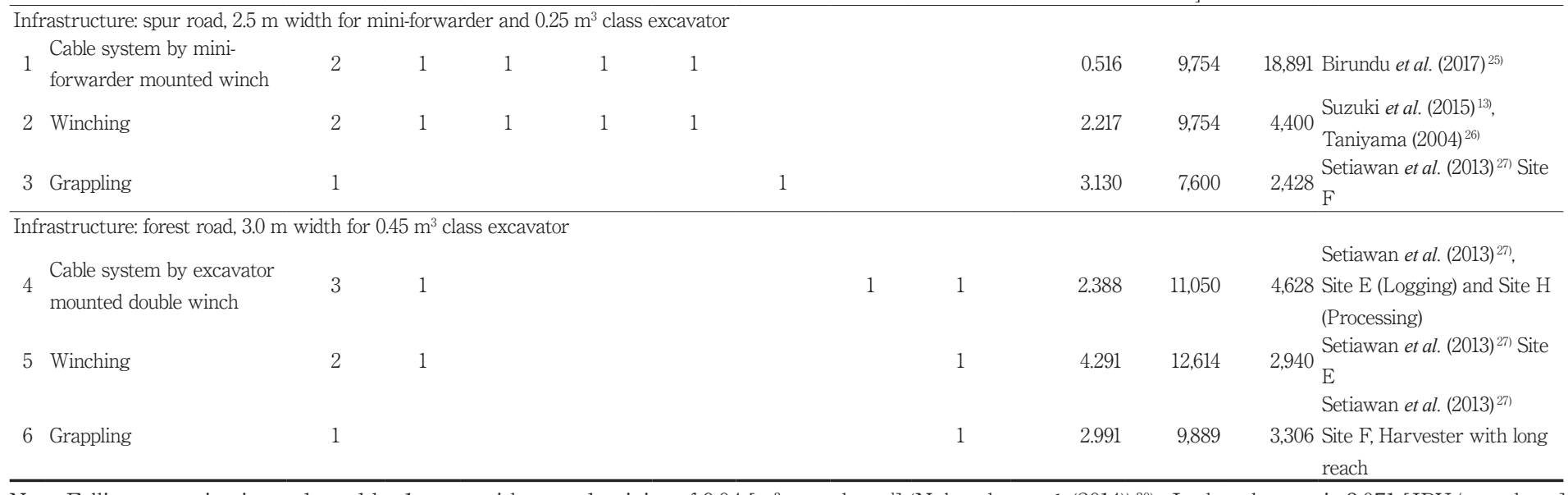

Note: Felling operation is conducted by $1 \mathrm{crew}$ with a productivity of $9.04\left[\mathrm{~m}^{3} \cdot \mathrm{crew}^{-h o u r}{ }^{-1} \text { (Nakataha et al. }(2014)\right)^{30}$. Its hourly cost is 3,071 [JPY/crew-hour] and its resulting cost is $340\left[\mathrm{JPY} \cdot \mathrm{m}^{-3}\right]$.

$\left.\cdot \mathrm{m}^{-3}\right]$ よりも高くなっている。これは, 生産性の值を参照し た事例が適切でなかった可能性もあるが, これら2つのモー ドは経費面では大きく変わらないということを示唆している とも解釈できる。なお，実際に $3.0 \mathrm{~m}$ 幅員の高規格作業道 路網を $200\left[\mathrm{~m} \cdot \mathrm{ha}^{-1}\right]$ の高密度で広範囲の森林区域にわたつ て作設することは斜面崩壊などの危険性が高く，限られた区 域での適用にとどまると考えられる。

また，Table 8 において，モード1と2では集材方法は異 なるが，作業システムにおける機械のセットと作業員の組人 数は同じであるため，人件費を含む組作業経費は 9,754［円 ・組 -1. 時 -1] と同一である。しかし, 生産性はそれぞれ 0.516 $\left[\mathrm{m}^{3}\right.$ ・組 ${ }^{-1}$ ・時 $\left.{ }^{-1}\right]$ およよひ $2.217\left[\mathrm{~m}^{3}\right.$ ・組 ${ }^{-1}$. 時 $\left.{ }^{-1}\right]$ と約 4 倍の開 きがある。そのため, 材積あたりの伐出経費もそれぞれ 18,891 [円 $\cdot \mathrm{m}^{-3}$ ] と 4,440 [円 $\left.\cdot \mathrm{m}^{-3}\right]$ のように前者は後者の約 4 倍で, 針葉樹の一般用材の市場価格 $1.0 \sim 1.5$ 万円程度 ${ }^{13)}$ を超 える值となっている。林内作業車のウインチを用いた軽架線 集材は，機械の経費は手頃であるが，ウインチの巻き取り 速度が高くないこともあり生産性は低い。こうした，生産性 は低いが機械費用も低い作業システムは自家労働の個人林
家などで多く用いられる ${ }^{15)}$ ○そのような事例では，人件費 を雇用労働として経費を算出すると赤字になるが, 自家労働 として人件費をゼロあるいは一般の雇用労働より低い值とみ なすと妥当な収支となる場合があることから，現実にはより 低い人件費で運用されている可能性が指摘されている $\left.{ }^{13)} 15\right)$ なお，広葉樹材の販売価格はチップ材としてだと 4,000［円 $\cdot \mathrm{m}^{-3}$ 程度であるが, FIT 制度により木質発電用の未利用材 として取り扱われる場合には 9,984 [円· $\mathrm{m}^{-3}$ ] で買い取られ ると福田ら (2019) 10) は試算している。また樹種と用途によ るが，大径材で需要がある樹種ならば 30,000～90,000［円 $\cdot \mathrm{m}^{-3}$ ] で販売可能という報告もある ${ }^{17)}{ }^{18)}$ 。

これらの值を用いて (2) 式により，低効率モードから高 効率モードに移行した場合に投資効果が正となる集材量 $L_{2}-L_{1}\left[\mathrm{~m}^{3} \cdot \mathrm{ha}^{-1}\right]$ を求めた (Table 9, 10)。ただしモード5か ら 6への移行については值がマイナスとなるため示していな い。表に示された值は，モードの移行に必要な路網開設量 $\left[\mathrm{m} \cdot \mathrm{ha}^{-1}\right]$ に要した費用を投資として，その投資により可能と なったより単価の低い作業システムによる伐出経費の低減分 が，投資を上回るのに必要な ha あたりの伐出量を意味して 
Table 9 Logged volume $L_{2}-L_{1}\left[\mathrm{~m}^{3} \cdot \mathrm{ha}^{-1}\right]$ on cost [JPY $\cdot \mathrm{ha}^{-1}$ ] for $2.5 \mathrm{~m}$ width road network

\begin{tabular}{c|ccr}
\hline \multirow{2}{*}{ 1st mode } & \multicolumn{4}{|c}{ 2nd mode } \\
& 1 & 2 & 3 \\
\hline 1 & & & 10.4 \\
2 & N.A. & N.A. & 18.2 \\
3 & N.A. & N.A.1 & \\
\hline
\end{tabular}

Table 10 Logged volume $L_{2}-L_{1}\left[\mathrm{~m}^{3} \cdot \mathrm{ha}^{-1}\right]$ on cost [JPY ha- $\left.{ }^{-1}\right]$ for $3.0 \mathrm{~m}$ width forest road network

\begin{tabular}{c|ccc}
\hline 1st mode & \multicolumn{4}{|c}{ 2nd mode } \\
& 4 & 5 & 6 \\
\hline 4 & N.A. & & \multicolumn{2}{c}{529.8} \\
5 & N.A. & N.A. & \\
6 & & & \\
\hline
\end{tabular}

$*:-1,909.3\left[\mathrm{~m}^{3} \cdot \mathrm{ha}^{-1}\right]$

いる。低規格路網のモード1からモード 2 あいは3への移 行ではその材積は $10 \sim 18\left[\mathrm{~m}^{3} \cdot \mathrm{ha}^{-1}\right]$ で, 適度な間伐で十分 達成できる量である。一方モード 2 からモード3への移行で は $152\left[\mathrm{~m}^{3} \cdot \mathrm{ha}^{-1}\right]$ とその量は多くなる。森林簿における広葉 樹林の蓄積は，抢そらく正確な調査がされていないことから 一律 $100 \sim 120\left[\mathrm{~m}^{3} \cdot \mathrm{ha}^{-1}\right]$ 程度となっている場合が多い 8) 10) が, 鈴木ら (2016) ${ }^{8)}$ の調查事例では胸高直径 $15 \mathrm{~cm}$ 以上に 限っても $200 \sim 300\left[\mathrm{~m}^{3} \cdot \mathrm{ha}^{-1}\right]$ の蓄積量が確認された。しか し利用率 $\left(0.6 \sim 0.7\right.$ 程度 $\left.{ }^{8}{ }^{10)}\right)$ を考慮すると, $152\left[\mathrm{~m}^{3} \cdot \mathrm{ha}^{-1}\right]$ の収穫量を達成するためには, 皆伐に近い伐採率が必要と 考えられる。

高規格路網のモード 4 からモード 5 あるいは 6 の移行で は, $210 \sim 530\left[\mathrm{~m}^{3} \cdot \mathrm{ha}^{-1}\right]$ 程度の伐採量が必要という結果と なった (Table 10)。広葉樹林の一般的な haあたり蓄積量 を考えると, この伐採量を達成することは難しい。すなわち, この結果は, 広葉樹林の伐出には高規格作業道を用いる作 業システムは適さないということを示唆していると考えられ る。

なお，集材の生産性は針葉樹人工林間伐の実績值を用い たが, 広葉樹を対象とした場合はこれに比して生産性は低下 すると考えられる。単純な仮定ではあるが既往の研究からそ の程度を 2 割程度 28) 29) とすると, Table 8 の伐出経費は 2 割程度増加し, Table 9 および Table 10 に示されているモー ド間の損益分岐に関わる数值は 2 割程度減少する。その場 合, 特に数值の大きな高規格作業道を用いる作業システムに おいて影響が大きく，モード4から 5 への移行に必要な伐採 量については $170\left[\mathrm{~m}^{3} \cdot \mathrm{ha}^{-1}\right]$ 程度となり, 蓄積量の大きい広 葉樹林では達成の現実性は高くなる。

\section{4. 結 言}

林地残材などの木質バイオマスを収穫・運搬する作業にお いて, 効率改善のための投資に見あう仕事量を求める簡便な 定式化を提案した。提案された定式化の方法を $2 つ$ 事例 に適用した。林地残材運搬を対象として運搬モードをより大
規模なものに移行するために, 中間土場を設けて積み替えを 投資とみなす第 1 の事例では，単位量あたり投資および環境 負荷に関して二酸化炭素排出量とエネルギー消費を指標とし た結果, 最も小規模な軽トラックの非効率性と中規模の $4 \mathrm{t}$ トラックの相対的高効率性が明らかとなった。路網を整備し てより短距離で効率の高い伐出方式の導入を試みる第 2 の 事例では, 針葉樹よりも面積あたり蓄積量が少ない広葉樹 林に扔いては, 低規格作業道の路網と比較的小さな機械に よるシステムの方が, 高規格作業道の路網とより大きな機械 によるシステムよりも適していることが明らかとなった。

\section{謝 辞}

本研究は, 高知大学自然科学系プロジェクト・農学部門サ ブプロジェクト「バイオマス〜 TOSA」, および文部科学省科 研費 (基盤 B 一般研究 (課題番号 15H04508), 基盤 C一般 研究 (課題番号 16K07779), 基盤 C 特設分野研究 (課題番 号 18KT0090））の，また第 14 回バイオマス科学会議におけ る発表に際しては (公財) 高橋産業経済研究財団の支援を受 けた。

\section{文 献: References}

1) Mori, H., J. Jpn. For. Eng. Soc., 28, 73-78 (2013) : 森大顕, 森利誌, 28, 73-78 (2013)

2) Suzuki, Y., J. Jpn. For. Eng. Soc., 30, 1-16 (2015):鈴木保志, 森利誌, 30, 11-16 (2015)

3) Suzuki, Y., Life Environ., 725, 37-41 (2016) : 鈴木保志, 生 活と環境, 725, 37-41 (2016)

4) Suzuki, Y.; Aruga, K.; Yoshioka, T.; Toyama, K.; Saito, M.; Shirasawa, H.; Yamasaki, S., J. Jpn. For. Soc., 99, 272-277 (2017) : 鈴木保志, 有賀一広, 吉岡拓如, 當山啓介, 斎藤 仁志, 白澤紘明, 山㟝真, 日林誌, 99, 272-277 (2017)

5) Forestry Agency, Annual Report on Forest and Forestry in Japan - Fiscal Year 2018, Forestry Agency, (2018):林野庁, 平成 29 年度 森林·林業白書, 林野庁, (2018)

6) Iwaoka, M., J. For. Mech. Soc., 595, 10-14 (2003) : 岩岡正 博, 機械化林業, 595, 10-14 (2003)

7) Moriguchi, K.; Suzuki, Y.; Gotou, J.; Inatsuki, H.; Yamaguchi, T.; Shiraishi, Y.; Ohara, T., J. Jpn. For. Soc., 86, 121-128 (2004): 森口敬太, 鈴木保志, 後藤純一, 稲 月秀昭, 山口達也, 白石裕治, 小原忠, 日林誌, 86, 121128 (2004)

8) Suzuki, Y.; Yamasaki, S.; Watanabe, N.; Fukuda, Y., J. Jpn. For. Eng. Soc., 31, 85-91 (2016) : 鈴木保志, 山浐真, 渡辺直史, 福田雄治, 森利誌, 31, 85-91 (2016)

9) Suzuki, Y.; Fukuda, Y.; Yamaoka, Y.; Inai, Y., J. Jpn. Inst. Energy, 96, 436-440 (2017) : 鈴木保志, 福田雄治, 山岡 雄一郎, 稲井康秀, 日工六誌, 96, 436-440 (2017)

10) Fukuda, Y.; Suzuki, Y.; Osaki, S.; Iiguni, Y., J. Jpn. For. Eng. Soc., 34, 47-56 (2019): 福田雄治, 鈴木保志, 大崎優, 飯國芳明，森利誌，34, 47-56 (2019) 
11) Kamiizaka, M.; Kanzaki, K., Forest Operation Systems, Buneido, 1990:飯坂實, 神㟝康一 編, 森林作業システム学, 文英堂, (1990)

12) Forestry Agency, http://www.rinya.maff.go.jp/j/seibi/ saisei/pdf/romousaisyuu.pdff (Last access: 2019.2.16) : 林野庁, http://www.rinya.maff.go.jp/j/seibi/saisei/pdf/ romousaisyuu.pdff (Last access: 2019.2.16)

13) Suzuki, Y.; Setiawan, A. H.; Gotou, J., J. Jpn. For. Soc., 97, 191-202 (2015): 鈴木保志, Setiawan, A. H., 後藤純一, 日林誌, 97, 191-202 (2015)

14) Yamasaki, S.; Yamasaki, T.; Suzuki, Y.; Mitani, Y.; Morimoto, M.; Nagasawa, Y., J. Jpn. For. Eng. Soc., 33, 25-35 (2018) : 山㟝真, 山嶂敏彦, 鈴木保志, 三谷幸寛, 森本正延, 長澤佳暁, 森利誌, 33, 25-35 (2018)

15) Suzuki, Y.; Murakami, S.; Gotou, J.; Nakajima, K.; Kitahara, F.; Tarumi, A.; Nakayama, T.; Tanouchi, H., J. Jpn. For. Eng. Soc., 28, 41-50 (2013) : 鈴木保志, 村上晋平, 後藤純一, 中嶋健造, 北原文章, 垂水亜紀, 中山环夫, 田内裕之，森利誌, 28, 41-50 (2013)

16) Tanouchi, H.; Suzuki, Y.; Kitahara, F., in A System for Logging Residue Recovery, National Forestry Extension Association in Japan, pp. 26-41 (2016) : 田内裕之, 鈴木 保志，北原文章，林業改良普及双書 No.181 林地残材を 集めるしくみ，全国林業改良普及協会，pp. 26-41 (2016)

17) Tsubuku, T., Manual for Management of Satoyama Broad-Leaved Tree Forests with an Aid of Subsidy Programs, National Forestry Extension Association in Japan, (2008) : 津布久隆, 補助事業を活用した里山の広葉 樹林管理マニュアル，全国林業改良普及協会, (2008)

18) Tsubuku, T., Forest Management Practice on Aged Satoyama Forests with Timber and Non-Timber Forest Products, National Forestry Extension Association in Japan, (2017): 津布久隆，木材とお宝植物で収入を上げる 高齢里山林の林業経営術, 全国林業改良普及協会, (2017)

19) National Forestry Extension Association in Japan Ed., Management of Mechanization, National Forestry Extension Association in Japan, (2001) : 全国林業改良普 及協会編，機械化のマネジメント，全国林業改良普及協会， (2001)
20) Ministry of the Environment, Government of Japan, https://www.env.go.jp/earth/ondanka/supply_chain/ gvc/estimate_tool.html (Last access: 2019.4.13) : 環境省, https://www.env.go.jp/earth/ondanka/supply_chain/ gvc/estimate_tool.html (Last access: 2019.4.13)

21) Nakahata, C.; Komatsuzaki, M.; Aruga, K.; Takei, Y.; Yamaguchi, R.; Ito, K.; Murakami, A.; Saito, M.; Tasaka, T., J. Jpn. For. Eng. Soc., 26, 187-194 (2011)：仲畑力，小松 崎未来, 有賀一広, 武井裕太郎, 山口玲子, 伊藤要, 村 上文美，斎藤仁志，田坂聡明，森利誌，26, 187-194 (2011)

22) Gotou, J., J. For. Mech. Soc., 658, 1-6 (2008) : 後藤純一, 機械化林業, 658, 1-6 (2008)

23) Suzuki, Y.; Gotou, J.; Yamauchi, J.; Ohara, T., J. Jpn. For. Eng. Soc., 25, 91-96 (2010):鈴木保志, 後藤純一, 山内潤子, 小原忠, 森利誌, 25, 91-96 (2010)

24) Sundberg, U.; Silversides, R., Operational Efficiency in Forestry Vol. 1 Analysys, Kluwer Academic Publishers, (1988)

25) Birundu, A. O.; Suzuki, Y.; Gotou, J.; Nagai, H.; Hayata, Y.; Yamasaki, S.; Yamasaki, T., Proc. FORMEC the 49th Symposium on Forest Mechanization, Sept. 4-7, 2016, Warsaw, Poland, pp.99-103 (2017)

26) Taniyama, T., J. Jpn. For. Eng. Soc., 18, 257-258 (2004): 谷山徹, 森利誌, 18, 257-258 (2004)

27) Setiawan, A. H.; Suzuki, Y.; Gotou, J., J. Jpn. For. Eng. Soc., 28, 143-148 (2013)

28) Labelle, E. R.; Soucy, M.; Cyr, A.; Pelletier, G., Croat. J. For. Eng., 37, 175-183 (2016)

29) Labelle, E. R.; Bergen, M.; Windisch, J., Euro. J. For. Res., 136, 639-652 (2017)

30) Nakahata, C.; Aruga, K.; Uemura, R.; Saito, M.; Kanetsuki, K., Small-scale For., 13, 251-266 (2014)

31) Kochi Prefecture, Forestry Promotion and Environment Department, Central East Forestry Office, http://www. pref.kochi.lg.jp/soshiki/030203/files/2013082300164/ file_20176294154029_1.pdf (Last access: 2019.2.15) : 高知 県 林業振興 - 環境部 中央東林業事務所, http://www. pref.kochi.lg.jp/soshiki/030203/files/2013082300164/ file_20176294154029_1.pdf (Last access: 2019.2.15) 